\title{
Effect of Field Treatment on Microfloral Respiration and Storability of Canola under Different Storage Conditions
}

\author{
Fuji Jian1 ${ }^{*}$, Peian Tang2, Md. Abdullah Al Mamun1, Digvir S. Jayas ${ }^{1}$ \\ ${ }^{1}$ Department of Biosystems Engineering, University of Manitoba, Winnipeg, Canada \\ ${ }^{2}$ College of Food Science and Engineering, Nanjing University of Finance and Economics, Nanjing, China \\ Email: *Fuji.Jia n@umanitoba.ca
}

How to cite this paper: Jian, F.J., Tang, P.A., Al Mamun, Md.A. and Jayas, D.S. (2019) Effect of Field Treatment on Microfloral Respiration and Storability of Canola under Different Storage Conditions. American Journal of Plant Sciences, 10, 1989-2001. https://doi.org/10.4236/ajps.2019.1011139

Received: October 9, 2019

Accepted: November 12, 2019

Published: November 15, 2019

Copyright $\odot 2019$ by author(s) and Scientific Research Publishing Inc. This work is licensed under the Creative Commons Attribution International License (CC BY 4.0).

http://creativecommons.org/licenses/by/4.0/

\begin{abstract}
Whether different field treatments such as straight cut, swathing, or pre-harvest aid application can influence the canola storage is the critical information for growers. The effect of these different field treatments on the infection and development of microflora on canola seeds with $9 \%, 11 \%$, and $14 \%$ moisture content at $20^{\circ} \mathrm{C}, 25^{\circ} \mathrm{C}, 30^{\circ} \mathrm{C}$ and $35^{\circ} \mathrm{C}$ was determined. To evaluate the microfloral infection and development, concentration of $\mathrm{CO}_{2}$ and $\mathrm{O}_{2}$ in $150 \mathrm{~g}$ canola bulks were measured every $3 \mathrm{~d}$. At the beginning and end of the study ( $66 \mathrm{~d}$ ), the seed moisture content, germination, visible mold, invisible fungal infection, and yellow seed count were measured. The swathed and nature ripened canola had a slightly higher respiration rate at $\geq 30^{\circ} \mathrm{C}$ and $\geq 2 \mathrm{wk}$ than the seeds with other field treatments. The swathed canola had a marginally lower initial germination and higher germination at $66 \mathrm{~d}$. The Glyphosate treated and nature ripened canola seeds had a slightly higher chance of visible model development. However, all these differences were not significant at $\alpha=0.05$ level and different field treatments and storage conditions did not influence the yellow seed count.
\end{abstract}

\section{Keywords}

Canola, Pre-Harvest Treatment, Pre-Harvest Aid, Respiration, Safe Storage

\section{Introduction}

Canada annually produces about 20 million tonnes of canola, which contributes $\$ 26.7$ billion dollars (CAD) to Canadian economy and is about one quarter of all farm income. Farmers harvest canola seeds by swathing, straight cutting, or straight cutting with the application of pre-harvest aids (referred to as field 
treatment) such as Glyphosate ( $\mathrm{N}$-(phosphonomethyl)glycine), Heat LQ (Group 14 saflufenacil), and Reglone (Diquat ion). These harvested seeds are stored in farm bins for up to one year. Under unsafe storage conditions, the stored seeds might be infected by microflora, which results in high respiration rates and quality reduction.

Glyphosate, Heat LQ, and Reglone are registered as pre-harvest perennial weedicide, desiccants and annual weed control, and fast dry down desiccants, respectively in Canada [1]. All of these registered chemicals can be used as pre-harvest aids because they can kill and/or desiccate crops and weeds. Glyphosate is absorbed by leaves and stems, transported within the plant, and prevents the production of a plant-specific enzyme (5-enolpyruvylshikimate3-phosphate synthase) which leads to plant death by starvation [2]. This slow process requires $1-3 \mathrm{wk}$ and it may end up in the seed as herbicide residues if Glyphosate is applied earlier when the plant is still actively translocating nutrients to the seed kernels. Reglone does not hasten crop maturity, but ruptures the outer layer of cellular membrane of plant cells. Reglone has an acting period of $4-7 \mathrm{~d}$ and the plant dries down faster than it would without Reglone application when the plant is exposed to sun. After Heat LQ is rapidly absorbed by root, leaves, and stems, it inhibits protoporphyrinogen oxidase, which results in cell membrane damage and leads to plant death and drydown. Heat LQ has an acting period of $3-5 \mathrm{~d}$ and provides a broad spectrum weed control and improves crop uniformity for harvesting. It has been reported that germination of canola is not influenced by Reglone and Heat LQ [3], but Glyphosate reduces germination if it is applied when the pods are green and when seed moisture content is high [1]. Therefore, different harvest methods and use of chemical desiccants may influence the physiological status of the plants and seeds, hence affect the initial storage condition of canola.

The initial storage condition includes oilseed temperature, moisture content (MC) (in this manuscript MC are on wet basis unless noted otherwise), relative humidity $(\mathrm{RH})$, maturity, pre-harvest treatment, seed vigor, and microfloral infection. After canola is harvested and binned, canola may have a high respiration rate for up to $6 \mathrm{wk}$ [4] [5] [6]. A high percentage of green seeds might accelerate the respiration and deterioration of stored canola [7] [8] [9]. Higher respiration of stored canola will produce heat and water which might result in hotspot development [4]. Jian et al. (unpublished data) found canola seeds with different field treatments had different equilibrium RHs at the same moisture content and temperature of the seeds. The swathed canola had a significant lower initial germination at all storage conditions studied and higher germination at the storage condition of $35^{\circ} \mathrm{C}$ and $75 \% \mathrm{RH}$ than any canola seeds with different field treatments at 12 wk. At $93 \% \mathrm{RH}$, the yellow seed count increased with the storage time except for the swathed canola. Different field treatments had different fungal species with different initial infections.

Respiration of seeds under different stored conditions is usually determined by measuring $\mathrm{CO}_{2}$ production and $\mathrm{O}_{2}$ consumption [5] [10]. These determined 
$\mathrm{CO}_{2}$ and $\mathrm{O}_{2}$ concentrations indicate the development of microflora infecting the stored seeds because grain has negligible respiration rate under safe storage conditions [11] and most, if not all, the measured $\mathrm{CO}_{2}$ is produced by the microflora [5] [12]. Respiration rates of microflora in stored grain are usually much higher than that of the dry grain except when wet seeds sprout [13]. Therefore, $\mathrm{CO}_{2}$ concentrations measured in the interstitial air can facilitate early detection and level of spoilage in storage grain bulks [14]. It is not known whether different field treatments such as straight cutting, swathing, or desiccant application can influence the respiration of the seeds under different storage conditions.

The aim of this study was to measure the respiration of $9 \%, 11 \%$, and $14 \%$ MC canola seeds with different field treatments and stored at $20^{\circ} \mathrm{C}, 25^{\circ} \mathrm{C}, 30^{\circ} \mathrm{C}$, and $35^{\circ} \mathrm{C}$. The measured respirations were used to answer the question: whether the canola seeds with different field treatments have different spoilages or not? The field treated canola seeds were: the canola plants swathed (referred to as SW), Glyphosate applied + straight cut (referred to as GL), Heat LQ and Glyphosate applied + straight cut (referred to as HG), Reglone applied + straight cut (referred to as RE), and natural ripening + straight cut (referred to as NR). To evaluate the storability of the seeds under different storage conditions, MC, germination, visible and invisible mold, and yellow seed count were determined.

\section{Materials and Methods}

\subsection{Field Treatment and Seed Preparation}

Canola cultivar Bayer L233P was seeded on an 80-acre field located at about 20 $\mathrm{km}$ north of Winnipeg. Standard field practices including seeding date, pest and weed management, and fertility were applied to the field to maximize the canola production. The canola plants at different locations of the field had a similar growth rate and height before the field treatment. For the convenience of the pre-harvest treatment, the field was evenly divided into three zones in the North-East direction, and each zone was further divided into 10 plots in the same direction [15]. The width of a plot was two passes of a chemical sprayer or combine (10.7 to $16.7 \mathrm{~m}$ ). To avoid any treatment overlap, the canola plants between two passes $(3 \mathrm{~m})$ were cut before the chemical application. The following five pre-harvest treatments were applied to each zone (two plots per treatment) in the order of North to South direction: GL, RE, SW, HG, and NR. Therefore, there were total three replicates (including 6 passes) for each pre-harvest treatment. The application rates of the Reglone, Heat and Glyphosate, and Glyphosate were 25,15 , and 10 gals/acre $(233.85,140.31$, and $93.54 \mathrm{~L} / \mathrm{ha})$, respectively. The application times of Reglone, Heat and Glyphosate, and Glyphosate were 5, 9 , and $15 \mathrm{~d}$ before harvest, respectively. The wind speed during the chemical application period was less than $38 \mathrm{~km} / \mathrm{h}$. These application times and rates were recommended by the chemical manufacturer (Bayer CropScience Inc., Morrisville, NC, USA). The canola was swathed on August 28, 2017. The harvest times of the other four pre-harvest treatments were on August 29 and 30, 2017. Harv- 
est time was decided based on the farmer's experience, recommendations from the Canola Council of Canada, and from the pre-harvest aid manufacturer (Bayer CropScience Inc., Morrisville, NC, USA). A 35' MacDon draper header (MacDon, Winnipeg, MB, Canada) was used to straight cut the canola plants. Swathed treatments were harvested with a John Deere Pick-up header (John Deer S690, Grand Detour, IL, USA). All plots were combined with a John Deere S670 (Grand Detour, IL, USA). The auto-steer and GPS were used to ensure accuracy of spraying and harvesting. To limit the influence of field operation on the storage study, about $100 \mathrm{~kg}$ canola seeds were collected from each pass for each treatment, and the collected canola seeds with the same pre-harvest treatment and from the three zones (about $600 \mathrm{~kg}$ for each pre-harvest treatment) were mixed before lab study. All the harvested canola from different pre-harvest treatments had $10.5 \% \pm 0.5 \%$ moisture content $(\mathrm{MC})$.

After the harvested seeds were delivered to the lab, the $600 \mathrm{~kg}$ seeds for each pre-harvest treatment were cleaned using a hand sieve (No. 14, $5.56 \mathrm{~mm}$ openings) to separate larger materials (such as chaff) from the seeds, and mixed again by using a lab-fabricated mixture. After mixing, the canola MC was measured using ASABE standard [16] and the MC of the canola was $10.5 \% \pm 0.1 \%$. To achieve the desired $\mathrm{MC}$ of the canola, $150 \mathrm{~kg}$ of the seeds from each pre-harvest treatment were spread on a floor in a lab room. The lab room was at $27^{\circ} \mathrm{C} \pm 2^{\circ} \mathrm{C}$ and $40 \% \pm 5 \%$ relative humidity $(\mathrm{RH})$. The canola thickness on the floor was about $1 \mathrm{~cm}$ and a rake was used to mix the canola every $2 \mathrm{~d}$. The canola MC was measured every $1 \mathrm{~d}$ and $75 \mathrm{~kg}$ canola seeds were bagged in double layer plastic bags when the MC was $9.0 \% \pm 0.1 \%$. To achieve $11.0 \%$ MC canola, $1.264 \mathrm{~L}$ distilled water was added to $225 \mathrm{~kg}$ canola with $10.5 \% \pm 0.1 \% \mathrm{MC}$ and mixed in the mixture for $0.5 \mathrm{~h}$ [17]. One week later, this conditioned canola was mixed again for $0.5 \mathrm{~h}$. The same method was used to produce the $14.0 \% \pm 0.1 \% \mathrm{MC}$ canola. All the conditioned and bagged seeds were stored at $5^{\circ} \mathrm{C} \pm 1^{\circ} \mathrm{C}$ for at least $2 \mathrm{wk}$ before using. The MC of these conditioned canola seeds was measured again before the test and the MCs of these canola seeds were $9.0 \% \pm 0.1 \%, 11.0 \% \pm 0.1 \%$, and $14.0 \% \pm 0.1 \%$ (standard error was reported when a mean value was presented in this article). These adjusted MCs were reported as the initial MCs in this article.

\subsection{Measurement of $\mathrm{CO}_{2}$ and $\mathrm{O}_{2}$ Concentration}

Methods reported by Jian et al. [5] were used to measure the interstitial $\mathrm{CO}_{2}$ and $\mathrm{O}_{2}$ concentration of the canola seeds. The same Erlenmeyer flasks $(300 \mathrm{~mL})$ and setup as used by Jian et al. [5] were used in this study and $150 \mathrm{~g}$ canola seeds with a desired moisture content were filled in a flask. The flasks were sealed with rubber stoppers and kept in environmental chambers (Conviron CMP3244, Controlled Environments Ltd., Winnipeg, $\mathrm{MB}$, Canada) and temperatures of the environmental chambers were set at $20^{\circ} \mathrm{C} \pm 1{ }^{\circ} \mathrm{C}, 25^{\circ} \mathrm{C} \pm 11^{\circ} \mathrm{C}, 30^{\circ} \mathrm{C} \pm 1^{\circ} \mathrm{C}$, and $35^{\circ} \mathrm{C} \pm 1^{\circ} \mathrm{C}$. Concentrations of $\mathrm{CO}_{2}$ and $\mathrm{O}_{2}$ of gas samples were determined us- 
ing a procedure described by Jian et al. [5] and a Perkine Elmer Gas chromatograph (Model: Clarus 420. ON, Canada) equipped with a thermal conductivity detector was used. The setting of the chromatograph was: $30 \mathrm{~mL} / \mathrm{min}$ helium carrier gas, $150^{\circ} \mathrm{C}$ detector temperature, $70^{\circ} \mathrm{C}$ oven temperature, a 6 - $\mathrm{ft}(1.85-\mathrm{m})$ column ( $2 \mathrm{~mm}$ inside-diameter) packed with Hayesep $\mathrm{N} \mathrm{60/80} \mathrm{mesh} \mathrm{for} \mathrm{CO}_{2}$ measurement, and a $9-\mathrm{ft}(2.78-\mathrm{m}) 13 \times$ molecular sieve $40 / 60$ mesh column for $\mathrm{O}_{2}$ measurement. The gas chromatograph was calibrated using high purity mixtures of $\mathrm{CO}_{2}$ in $\mathrm{N}_{2}$ or $\mathrm{O}_{2}$ in helium (Matheson Tri-Gas, Morrow, Georgia, USA). Based on the $\mathrm{CO}_{2}$ concentrations and their corresponding areas calculated by the integrator of the Perkine Elmer gas chromatograph, a regression equation was developed, and this regression equation was used to determine the $\mathrm{CO}_{2}$ concentration inside each flask. The same method was used to determine the $\mathrm{O}_{2}$ concentration.

Concentrations of $\mathrm{CO}_{2}$ and $\mathrm{O}_{2}$ in each flask were measured every $3 \mathrm{~d}$ by sampling $4 \mathrm{~mL}$ gases $\left(2 \mathrm{~mL}\right.$ gas sample for $\mathrm{CO}_{2}$ and $2 \mathrm{~mL}$ gas sample for $\mathrm{O}_{2}$ measurement). To manage the work load, the respiration of seeds with $9.0 \% \pm 0.1 \%$, $11.0 \% \pm 0.1 \%$, and $14.0 \% \pm 0.1 \% \mathrm{MCs}$ and stored at $25^{\circ} \mathrm{C} \pm 1{ }^{\circ} \mathrm{C}$, and the seeds with $11.0 \% \pm 0.1 \% \mathrm{MC}$ and stored at $20^{\circ} \mathrm{C} \pm 1^{\circ} \mathrm{C}, 30^{\circ} \mathrm{C} \pm 1^{\circ} \mathrm{C}$, and $35^{\circ} \mathrm{C} \pm 1^{\circ} \mathrm{C}$ were measured. After the gas was sampled, canola seeds inside the flask were slowly transferred to another flask and then transferred back to the same flask by using a funnel $(6.0-\mathrm{cm}$ high and $6.0-\mathrm{cm}$ diameter top opening and $0.8-\mathrm{cm}$ outer-diameter spout) [5]. This transfer procedure would replace the $\mathrm{CO}_{2}$ and $\mathrm{O}_{2}$ inside the flasks with room air. The respiration measurement was stopped at 66 $\mathrm{d}$ of the storage time.

\subsection{Measurement of Storage Parameters}

Before and at the end of this study, the following parameters were measured: MC [16], seed germination (percentage), visible mold (fungal species and infection percentage), invisible fungal infection (fungal species and infection percentage), and green/yellow seed count (percentage). About $10 \mathrm{~g}$ seeds were used to determine the MC.

Germination was determined by putting 25 kernels in a $9 \mathrm{~cm}$ diameter petri dish with a filter paper and $5 \mathrm{~mL}$ distilled water [18]. The kernels were incubated at room temperature $\left(25^{\circ} \mathrm{C} \pm 2^{\circ} \mathrm{C}\right)$, and the number of sprouted kernels was counted $7 \mathrm{~d}$ later. The germination was calculated using the numbers of the sprouted kernels divided the 25 seeds and multiplied by 100 .

To determine the visible mold infection, 25 kernels (without incubation) were observed under the dissecting microscope. The mold species were identified based on the color and shape of the mold colony. A kernel was count as an infected kernel if one or more than one colonies were found on the kernel, and the percentage of visible infection was calculated using the numbers of infected seeds divided the 25 seeds and multiplied by 100 . To determine the invisible mold, 25 kernels were put in a $9 \mathrm{~cm}$ diameter petri dish with a filter paper and 5 
$\mathrm{mL} 7.5 \%$ aqueous sodium chloride solution. After $7 \mathrm{~d}$ of incubation at the room temperature, invisible mold was identified using a dissecting microscope based on the color and shape of the microfloral colony [19] [20]. The percentage of the microfloral infection of each fungal species was calculated using the numbers of infected seeds divided the 25 seeds and multiplied by 100 .

Green and yellow seed counts were determined by following the Official Grain Grading Guide of Canadian Grain Commission [21]. Canola seeds were crushed using a plastic paddle ( 2 in diameter $\times 10$ inch length) and then masking tapes were used to keep 200 seeds on the paddle. A vinyl roller was used to crush the seeds, and the number of seeds (on the tapes) with green and yellow colour was counted and percentage of the yellow seeds was calculated and reported as the yellow seed count.

\subsection{Data Analysis}

A completely randomized design with three replicates at each treatment was conducted. To check whether the seeds with different field treatments had different respiration at the same storage condition and time, Paired t-test was conducted to compare the mean $\mathrm{CO}_{2}$ concentration of the seeds with different field treatments but at the same storage condition [22]. Tukey tests were conducted to compare the $\mathrm{CO}_{2}$ concentration associated with different field treatments but stored at the same condition and time. Student t-test was conducted to compare a storage parameter of the seeds at the same field treatment and same storage condition between at 0 and $66 \mathrm{~d}$ of storage time.

\section{Results and Discussion}

\subsection{Moisture Content}

The moisture content of the seeds at $66 \mathrm{~d}$ was not significantly different from their initial moisture contents (Student $\mathrm{t}$-test, all $\mathrm{t} \leq 1.902$, all $p \geq 0.130, \mathrm{df}=4$ ) and there was no significant difference among the seeds with different field treatments and stored at the same condition (Tukey test, all $\mathrm{F} \leq 3.158, p \geq$ $0.064)$. However, the standard error of the moisture content of the seeds was increased from the initial $\leq 0.1 \%$ to the final $0.3 \%$ to $0.4 \%$. Therefore, the canola seeds with different field treatments were approximately stored at the constant moisture contents in this study.

\subsection{Concentration of $\mathrm{CO}_{2}$ and $\mathrm{O}_{2}$}

The $\mathrm{CO}_{2}$ concentrations in the interstitial air of the seeds stored at higher temperatures and/or higher MCs were higher than that at lower temperatures and lower MCs (Figure 1). This was consistent with the literatures [5] [6] [14]. The $\mathrm{O}_{2}$ concentration was low when the $\mathrm{CO}_{2}$ concentration was high (Figure 2), and the sum of the $\mathrm{CO}_{2}$ and $\mathrm{O}_{2}$ concentrations was about $21 \%$ [5]. This indicated the microflora consumed one $\mathrm{O}_{2}$ and produced one $\mathrm{CO}_{2}$ at the same time, and carbohydrate was mostly used as the substrate and consumed by microflora during 

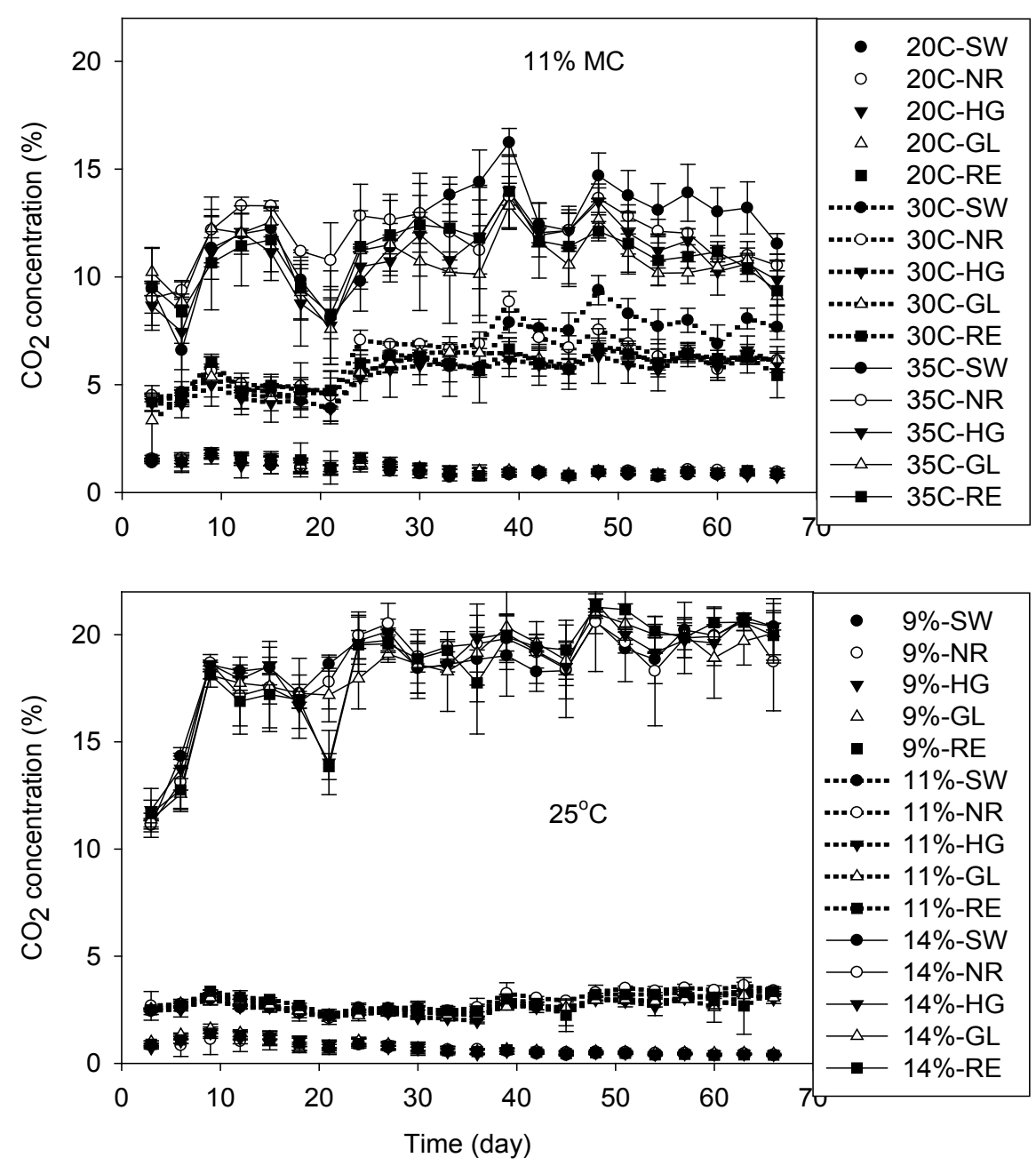

Figure 1. Measured $\mathrm{CO}_{2}$ concentration of canola seeds with $11 \%$ moisture content and stored at different temperatures (top) or the seeds with $9,11 \%$, and $14 \%$ moisture contents at $25^{\circ} \mathrm{C}$ (bottom). The plants were swathed (SW), natural ripening + straight cut (NR), Heat LQ and Glyphosate applied + straight cut (HG), Glyphosate applied + straight cut (GL), and Reglone applied + straight cut (RE).

their respiration [23]. The main composition of rapeseed (canola) hull is non-lignified biomass which contains about $60 \%$ holocellulose, $14 \%$ protein, and minimum amount of lipids [24]. These main carbohydrate components might be used by the microflora in the tested period, and the microflora did not consume or consumed a negligible amount of lipids which are located inside the hull of the canola seeds.

There were no significant differences of the $\mathrm{CO}_{2}$ concentrations produced in the $14 \%$ MC seeds with different field treatments (Table 1), while there were significant differences at other storage conditions in $52 \%$ cases. These significant differences were caused by the fluctuated $\mathrm{CO}_{2}$ concentrations (Figure 1). For example, the mean $\mathrm{CO}_{2}$ concentrations of the SW, NR, HG, GL, and RE canola with $11 \% \mathrm{MC}$ and stored at 35 and at $39 \mathrm{~d}$ were $16.2 \% \pm 0.7 \%, 13.7 \% \pm 1.5 \%$, $14.0 \% \pm 0.7,13.3 \% \pm 1.0 \%$, and $14.0 \% \pm 1.7 \%$, respectively; and at $42 \mathrm{~d}$ were 

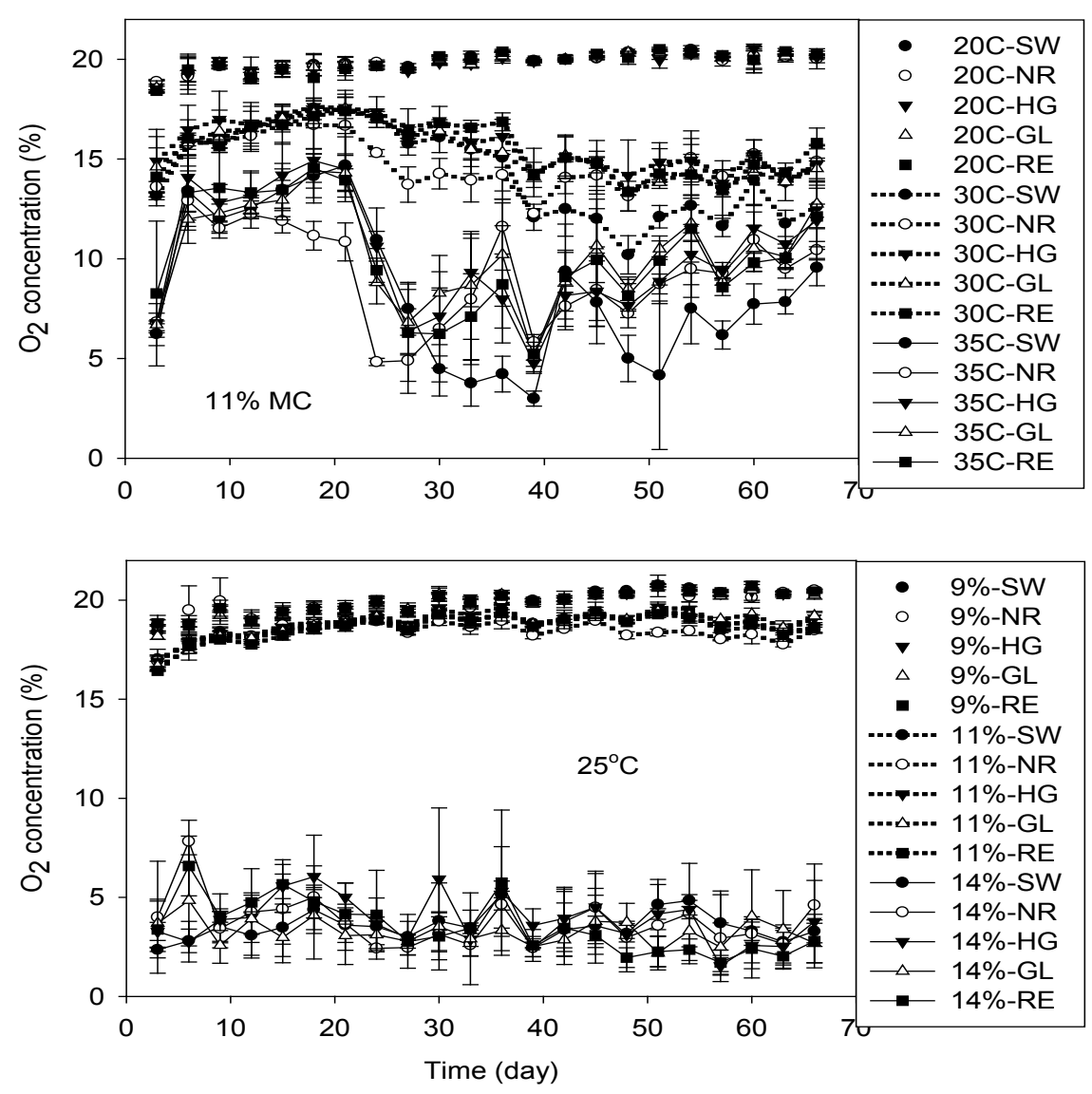

Figure 2. Measured $\mathrm{O}_{2}$ concentration of canola seeds with $11 \%$ moisture content and stored at different temperatures (top) or the seeds with $9 \%, 11 \%$, and $14 \%$ moisture contents at $25^{\circ} \mathrm{C}$ (bottom). The plants were swathed (SW), natural ripening + straight cut (NR), Heat LQ and Glyphosate applied + straight cut (HG), Glyphosate applied + straight cut (GL), and Reglone applied + straight cut (RE).

Table 1. The $\mathrm{p}$ values of the Paired t-test to compare the $\mathrm{CO}_{2}$ concentration produced by canola with different field treatments and under the same storage conditions.

\begin{tabular}{|c|c|c|c|c|c|c|}
\hline \multirow{3}{*}{$\begin{array}{l}\text { Field } \\
\text { treatment }\end{array}$} & \multicolumn{6}{|c|}{ Storage conditions } \\
\hline & $11 \% \mathrm{MC}$ & $11 \% \mathrm{MC}$ & $11 \% \mathrm{MC}$ & $11 \% \mathrm{MC}$ & $9 \% \mathrm{MC}$ & $14 \% \mathrm{MC}$ \\
\hline & $20^{\circ} \mathrm{C}^{\ddagger}$ & $25^{\circ} \mathrm{C}^{\ddagger}$ & $30^{\circ} \mathrm{C}^{\ddagger}$ & $35^{\circ} \mathrm{C}^{\ddagger}$ & $25^{\circ} \mathrm{C}^{\ddagger}$ & $25^{\circ} \mathrm{C}^{\ddagger}$ \\
\hline $\mathrm{SW}-\mathrm{NR}^{\dagger}$ & $<0.001^{* *}$ & $<0.001^{\star *}$ & 0.395 & 0.616 & 0.523 & 0.533 \\
\hline $\mathrm{SW}-\mathrm{HG}^{\dagger}$ & $0.047^{\star}$ & $0.016^{\star}$ & $<0.001^{\star \star}$ & $<0.001^{\star *}$ & 0.089 & 0.773 \\
\hline $\mathrm{SW}-\mathrm{GL}^{\dagger}$ & $<0.001^{\star \star}$ & 0.784 & $0.002^{*}$ & $0.002^{*}$ & $0.001^{\star *}$ & 0.366 \\
\hline SW-RE ${ }^{\dagger}$ & $<0.001^{* *}$ & 0.046 & $0.008^{*}$ & $0.002^{*}$ & $0.004^{*}$ & 0.611 \\
\hline $\mathrm{NR}-\mathrm{HG}^{\dagger}$ & $0.034^{*}$ & $<0.001^{\star *}$ & $0.001^{*}$ & $<0.001^{* *}$ & 0.749 & 0.910 \\
\hline NR-GL ${ }^{\dagger}$ & 0.366 & $<0.001^{\star \star}$ & $<0.001^{\star *}$ & $<0.001^{\star \star}$ & 0.061 & 0.645 \\
\hline NR-RE ${ }^{\dagger}$ & 0.450 & 0.106 & $0.002^{*}$ & $<0.001^{\star *}$ & 0.510 & 0.828 \\
\hline $\mathrm{HG}-\mathrm{GL}^{\dagger}$ & $0.028^{*}$ & 0.138 & $0.002^{*}$ & 0.468 & $0.029^{*}$ & 0.580 \\
\hline $\mathrm{HG}-\mathrm{RE}^{\dagger}$ & $0.009^{*}$ & $0.001^{*}$ & $<0.001^{\star *}$ & 0.485 & 0.644 & 0.634 \\
\hline $\mathrm{GL}^{-R E^{\dagger}}$ & 0.107 & $0.008^{*}$ & 0.580 & 0.155 & $0.007^{*}$ & 0.875 \\
\hline
\end{tabular}

${ }^{\dagger}$ Comparison between field treatments (Paired t-test). SW, NR, HG, GL, and RE are the swathed, natural ripening + straight cut, Heat and Glyphosate applied + straight cut, Glyphosate applied + straight cut, and Reglone applied + straight cut canola. ${ }^{\text {T}}$ The $\mathrm{p}$ value of the Paired $\mathrm{t}$-test is presented in the columns at each of the storage conditions. * ${ }^{*}$ significant at $\alpha=0.05$ level. 
$12.4 \% \pm 1.0 \%, 12.0 \% \pm 0.3 \%, 12.0 \% \pm 0.7 \%, 11.6 \% \pm 0.7 \%$, and $11.7 \% \pm 1.7 \%$, respectively. These fluctuations might not occur inside grain storage bins because the interstitial air inside the seeds were replaced for every $3 \mathrm{~d}$ during this study and high $\mathrm{CO}_{2}$ and low $\mathrm{O}_{2}$ concentrations will inhibit the aerobic respiration in bins if the grain bulks are not aerated.

There was no significant difference of $\mathrm{CO}_{2}$ concentration associated with the seeds with different field treatments and stored at the same condition and time (Tukey test, all $\mathrm{F} \leq 0.525, p \geq 0.720, \mathrm{df}=14$ ). Therefore, the seeds with different field treatments had the similar respiration rate. At $35^{\circ} \mathrm{C}$, the $\mathrm{NR}$ canola with $11 \% \mathrm{MC}$ at 14 to $27 \mathrm{~d}$ and the SW canola with $11 \% \mathrm{MC}$ at 33 to $66 \mathrm{~d}$ had a consistent higher $\mathrm{CO}_{2}$ concentration than that of the canola seeds treated with other field treatments (Figure 1). These also occurred for the NR and SW canola at $30^{\circ} \mathrm{C}$. The high concentration of $\mathrm{CO}_{2}$ indicated a faster growth of microflora. Therefore, the swathed and nature ripened canola had a slightly higher respiration rate at higher temperatures (higher than $30^{\circ} \mathrm{C}$ ) when storage time is longer than 2 wks. This might be caused by the storage microflora infection before the swathed or nature ripened canola was collected from the field.

\subsection{Germination}

The initial germinations of the seeds were $\geq 96.0 \% \pm 3.9 \%$ except the swathed canola seeds (Table 2). One of the replicates of the SW canola seeds had $84 \%$ germination. This low initial germination might be caused by the microflora infection on the field before the swathed canola was collected. The seeds stored at $25^{\circ} \mathrm{C}$ had $\geq 92 \%$ germination (Table 2 ). The germinations of the $11 \% \mathrm{MC}$ seeds with different field treatments and stored at $35^{\circ} \mathrm{C}$ were significantly decreased at $66 \mathrm{~d}$ from the initial germination (Student $\mathrm{t}$-test, all $\mathrm{t} \geq 6.038$, all $p \leq 0.004, \mathrm{df}=$ 4 ). The decrease of the germination did not influence the production of $\mathrm{CO}_{2}$ and $\mathrm{O}_{2}$ consumption [25]. These results were consistent with the literatures [6] [20]. The SW canola at the end of this study had a slightly higher germination than the seeds with the other field treatments (Table 2), but this high germination

Table 2. Germination of the seeds with different field treatments and at different storage conditions.

\begin{tabular}{|c|c|c|c|c|c|c|}
\hline \multicolumn{2}{|c|}{ Storage condition ${ }^{\dagger}$} & \multicolumn{5}{|c|}{ Field treatments } \\
\hline $\mathrm{T}$ and time ${ }^{\dagger}$ & MC (\%) & SW & NR & $\mathrm{HG}$ & GL & $\mathrm{RE}$ \\
\hline \multirow{3}{*}{$\begin{array}{l}\text { Initial (0 day } \\
\text { storage time) }\end{array}$} & 9 & $100.0 \pm 0.0$ & $100.0 \pm 0.0$ & $98.7 \pm 2.3$ & $100.0 \pm 0.0$ & $98.7 \pm 2.3$ \\
\hline & 11 & $97.3 \pm 4.6$ & $98.7 \pm 2.3$ & $100.0 \pm 0.0$ & $96.0 \pm 3.9$ & $97.3 \pm 2.3$ \\
\hline & 14 & $94.7 \pm 9.2$ & $97.3 \pm 2.3$ & $97.3 \pm 2.3$ & $97.3 \pm 4.6$ & $98.7 \pm 2.3$ \\
\hline $25^{\circ} \mathrm{C}$ at $66 \mathrm{~d}$ & 14 & $98.0 \pm 2.8$ & $96.0 \pm 4.0$ & $92.0 \pm 6.9$ & $98.7 \pm 2.3$ & $96.0 \pm 6.9$ \\
\hline $35^{\circ} \mathrm{C}$ at $66 \mathrm{~d}$ & 11 & $50.7 \pm 4.6$ & $45.3 \pm 6.1$ & $36.0 \pm 6.9$ & $48.0 \pm 10.6$ & $45.3 \pm 8.3$ \\
\hline
\end{tabular}

${ }^{\dagger} \mathrm{T}=$ temperature, Time $=$ storage time, $\mathrm{MC}=$ moisture content. The germination of seeds at other storage conditions $\left(20^{\circ} \mathrm{C}\right.$ at any moisture content, $25^{\circ} \mathrm{C}$ at 11 , and $9 \%$ moisture content, and $30^{\circ} \mathrm{C}$ at $11 \%$ moisture content) with $66 \mathrm{~d}$ of storage time were higher than $94.7 \%$. ${ }^{\star} \mathrm{SW}, \mathrm{NR}, \mathrm{HG}, \mathrm{GL}$, and RE are the swathed, natural ripening + straight cut, Heat and Glyphosate applied + straight cut, Glyphosate applied + straight cut, and Reglone applied + straight cut canola. 
of SW seeds was not significantly different from the seeds with the other field treatments (Tukey test, $\mathrm{F}=0.531, p=0.716, \mathrm{df}=14$ ).

\subsection{Visible and Invisible Mold}

No visible mold was found at the beginning of the storage. At $66 \mathrm{~d}$, Aspergilus candidus was the only visible mold infecting the kernels, and no visible mold was found on the kernels stored at $20^{\circ} \mathrm{C}$, or 9 and $11 \% \mathrm{MC}$ seeds at $25^{\circ} \mathrm{C}$. These results were consistent with the literatures [20]. The maximum infection percentage of visible mold was $12 \%$ which was observed on NR canola with $11 \%$ $\mathrm{MC}$ and at $35^{\circ} \mathrm{C}$. At $35^{\circ} \mathrm{C}$, all the GL canola samples had visible mold. There was no significant difference of the infection percentage among the seeds with different field treatments. Therefore, field treatment might not influence the visible mold development, and GL and NR canola seeds had a slightly higher chance of visible model development.

The initial infection of the invisible mold was Alternaria alternata. The dominant fungal species at $66 \mathrm{~d}$ was Aspergilus glaucus. The other occasionally infected species were Penicilium spp. and A. candidus. The species of microflora were consistent with that reported by Jian et al. [5] and Sun et al. [20]. Almost $100 \%$ of kernels with any field treatment were infected by invisible mold at $66 \mathrm{~d}$ of the storage time (Table 3). These results were consistent with the literatures [5] [6] [20]. Therefore, different field treatments might not influence the microflora infection.

There were no green seeds in all of the samples. The initial yellow seed count of seeds with different field treatments was not significantly different. The initial yellow seed count of the seeds with different field treatments was $0.0044 \% \pm$ $0.0014 \%$. The yellow seed count was not significantly different in the seeds with different field treatments and stored at the same storage condition at $66 \mathrm{~d}$

Table 3. Percentage of infection (\%) of the visible mold (Aspergilus candidus) and invisible mold on canola seeds with different field treatments and at different storage conditions with $66 \mathrm{~d}$ of storage time.

\begin{tabular}{cccccccc}
\hline \multirow{2}{*}{ Mold } & \multicolumn{2}{c}{ Storage condition $^{\dagger}$} & \multicolumn{5}{c}{ Field treatments $^{\ddagger}$} \\
\cline { 2 - 7 } & $\mathrm{T}\left({ }^{\circ} \mathrm{C}\right)$ & $\mathrm{MC}(\%)$ & $\mathrm{SW}$ & $\mathrm{NR}$ & $\mathrm{HG}$ & $\mathrm{GL}$ & $\mathrm{RE}$ \\
\hline \multirow{2}{*}{ Visible $^{\ddagger}$} & 25 & 14 & $0.0 \pm 0.0$ & $1.3 \pm 1.3$ & $1.3 \pm 1.3$ & $0.0 \pm 0.0$ & $1.3 \pm 1.3$ \\
& 30 & 11 & $1.3 \pm 1.3$ & $0.0 \pm 0.0$ & $0.0 \pm 0.0$ & $2.7 \pm 2.7$ & $0.0 \pm 0.0$ \\
& 35 & 11 & $1.3 \pm 1.3$ & $4.0 \pm 4.0$ & $0.0 \pm 0.0$ & $4.0 \pm 0.0$ & $2.7 \pm 2.7$ \\
Invisible & 25 & 9 & $100 \pm 0.0$ & $100 \pm 0.0$ & $90.7 \pm 3.5$ & $96.0 \pm 2.3$ & $98.7 \pm 1.3$ \\
& 20 & 11 & $89.3 \pm 1.3$ & $89.3 \pm 1.3$ & $97.3 \pm 1.3$ & $96.0 \pm 2.3$ & $94.7 \pm 1.3$ \\
\hline
\end{tabular}

${ }^{+} \mathrm{T}=$ temperature, and $\mathrm{MC}=$ moisture content. ${ }^{\ddagger} \mathrm{SW}, \mathrm{NR}, \mathrm{HG}, \mathrm{GL}$, and RE are the swathed, natural ripening + straight cut, Heat and Glyphosate applied + straight cut, Glyphosate applied + straight cut, and Reglone applied + straight cut canola. ${ }^{*}$ The percentage of visible mold infection at other storage conditions $\left(20^{\circ} \mathrm{C}\right.$ at any moisture content, and $25^{\circ} \mathrm{C}$ at 11 and $9 \%$ moisture content) with $66 \mathrm{~d}$ of storage time were $0.0 \% \pm$ $0.0 \%$. 'The percentage of invisible mold infection at other storage conditions $\left(20^{\circ} \mathrm{C}\right.$ at any moisture content, and $25^{\circ} \mathrm{C}$ at $11 \%$ and $9 \%$ moisture content) with $66 \mathrm{~d}$ of storage time were $100.0 \% \pm 0.0 \%$. 
(Tukey test, all $\mathrm{F} \leq 2.514$, and all $p \geq 0.101$, $\mathrm{df}=17$ ). The yellow seed count was not significantly different in the seeds with different storage conditions at $66 \mathrm{~d}$ and the same field treatment (Tukey test, all $\mathrm{F} \leq 2.871$, and all $p \geq 0.062$, $\mathrm{df}=$ 17). There was no significant difference of the yellow seed count between at the 0 and $66 \mathrm{~d}$ for each field treatment and each storage condition (Student t-test, all $\mathrm{t}$ $\leq 1.512$, all $p \geq 0.205, \mathrm{df}=4$ ). Green seed count of canola at the harvest is not influenced by preharvest applications of glyphosate [1]. Therefore, different field treatments and storage conditions did not influence the yellow seed count. To the best of our knowledge, there is no study on the yellow seed reduction during storage periods. Several studies were conducted on green seed counts and the chlorophyll content. Canada swathed and then dried at $40^{\circ} \mathrm{C}$ can reduce chlorophyll content [26]. Air ventilation of stored canola can decrease the chlorophyll content in seeds [27]. Our study on the yellow seed count was inconsistent with this conclusion.

\section{Conclusions}

1) Even though the seeds with different field treatments had not a significant difference in respiration rate, the swathed and nature ripened canola had slightly higher respiration rate at higher temperatures (higher than $30^{\circ} \mathrm{C}$ ) when storage time was longer than 2 wks.

2) The swathed canola had a slightly lower germination at the beginning and higher germination at $66 \mathrm{~d}$ than the seeds with the other field treatments, but this high germination was not significant.

3) Field treatments did not influence the visible and invisible mold development, but Glyphosate treated and nature ripened canola seeds had a marginally higher chance of visible model development.

4) Different field treatments and storage conditions did not influence the yellow seed count.

\section{Acknowledgements}

We thank the Prairie Agricultural Machinery Institute (PAMI), Natural Sciences and Engineering Research Council of Canada (NSERC) for partial funding of this study, and Canada Foundation for Innovation, Manitoba Research Innovation Fund, and several other partners for creating research infrastructure. The authors are grateful to Colin Demianyk for preparing the saturated salt solutions.

\section{Conflicts of Interest}

The authors declare no conflicts of interest regarding the publication of this paper.

\section{References}

[1] Darwent, A.L., Kirkland, K.J., Townley-Smith, L., Harker, K.N. and Cessna, A.J. 
(2000) Effect of Preharvest Applications of Glyphosate on the Drying, Yield and Quality of Canola. Canadian Journal of Plant Science, 80, 433-439. https://doi.org/10.4141/P99-063

[2] Jordan, V.W.L. and Donaldson, G.V. (1996) Concept and Implementation Strategies for Rotaional Weed Control in Non-Inversion Tilage Systems. Aspects of Applied Biology, 47, 221-229.

[3] Canola Council of Canada (2019) Canolawatch, Canola Council of Canada. https://www.canolawatch.org/2017/2008/2023/the-dos-and-donts-of-desiccants

[4] Jian, F., Jayas, D.S. and White, N.D.G. (2014) Heat Production of Stored Canola Seeds under Airtight and Non-Airtight Conditions. Transactions of the ASABE, 57, 1151-1162. https://doi.org/10.13031/trans.57.10387

[5] Jian, F., Chelladurai, V., Jayas, D.S., Demianyk, C.J. and White, N.D.G. (2014) Interstitial Concentrations of Carbon Dioxide and Oxygen in Stored Canola, Soybean, and Wheat Seeds under Various Conditions. Journal of Stored Products Research, 57, 63-72. https://doi.org/10.1016/j.jspr.2013.12.002

[6] Pronyk, C., Muir, W.E., White, N.D.G. and Abramson, D. (2004) Carbon Dioxide Production and Deterioration of Stored Canola. Canadian Biosystems Engineering, 46, 3.25-23.33.

[7] Cenkowski, S., Sokhansanj, S. and Sosulski, F.W. (1989) Effect of Harvest Date and Swathing on Moisture Content and Chlorophyll Content of Canola Seed. Canadian Journal of Plant Science, 69, 925-928. https://doi.org/10.4141/cjps89-111

[8] Ohnson-Flanagan, A.M., Maret, J.L.D. and Pomeroy, M.K. (1994) Humidification of Green Canola Seed Leads to Pigment Degradation in the Absence of Germination. Crop Science, 34, 1618-1623. https://doi.org/10.2135/cropsci1994.0011183X003400060035x

[9] Green, B.R., Singh, S., Babic, I., Bladen, C. and Johnson-Flanagan, A.M. (1998) Relationship of Chlorophyll, Seed Moisture and ABA Levels in the Maturing Brassica napus Seed and Effect of a Mild Freezing Stress. Physiologia Plantarum, 104, 125-133. https://doi.org/10.1034/j.1399-3054.1998.1040116.x

[10] White, N.D.G., Sinha, R.N. and Muir, W.E. (1982) Intergranular Carbon Dioxide as an Indicator of Biological Activity Associated with the Spoilage of Stored Wheat. Canadian Agricultural Engineering, 24, 35-42.

[11] Hummel, B.C.W., Cuendet, S., Christensen, C.M. and Geddes, W.F. (1954) Grain Storage Studies. XIII. Comparative Changes in Respiration, Viability, and Chemical Composition of Mold-Free and Mold-Contaminated Wheat upon Storage. Cereal Chemistry, 31, 143-150.

[12] White, N.D.G., Sinha, R.N. and Muir, W.E. (1982) Rapid Determination of Seed Germination Potential to Measure Quality Loss in Stored Wheat. Canadian Journal of Plant Science, 62, 1045-1048. https://doi.org/10.4141/cjps82-155

[13] Magan, N., Sanchis, V. and Aldred, D. (2004) The Role of Spoilage Fungi in Seed Deterioration. In: Aurora, D.K., Ed., Fungal Biotechnology in Agricultural, Food and Environmental Applications, Marcel Dekker, New York, 311-323. https://doi.org/10.1201/9780203913369.ch28

[14] White, N.D.G., Sinha, R.N. and Muir, W.E. (1982) Intergranular Carbon Dioxide as an Indicator of Deterioration in Stored Rapeseed. Canadian Agricultural Engineering, 24, 43-49.

[15] Simundsson, A., Chorney, H. and Grieger, L. (2017) Straight Cutting Canola in Manitoba: Comparison of Pre-Harvest Aids. Prairie Agricultural Machinery Institute (PAMI), Portage La Prairie, 47. 
[16] ASABE (2016) Moisture Measurement-Unground Grain and Seeds, ASABE Standard. American Society of Agricultural and Biological Engineers, St. Joseph.

[17] Jian, F., Jayas, D.S. and White, N.D.G. (2013) Specific Heat, Thermal Diffusivity, and Bulk Density of Genetically Modified Canola with High Oil Content at Different Moisture Contents, Temperatures, and Storage Times. Transactions of the $A S A B E, 56,1077-1083$. https://doi.org/10.13031/trans.56.10067

[18] AACC (1962) AACC Approved Methods. Sixth Edition, American Association of Cereal Chemists, St. Paul, 154.

[19] Mills, J.T., Sinha, R.N. and Wallace, H.A.H. (1978) Multivariate Evaluation and Isolation Techniques for Fungi Associated with Stored Rapeseed. Phytopathology, 68, 1520-1525. https://doi.org/10.1094/Phyto-68-1520

[20] Sun, K., Jian, F., Jayas, D.S. and White N.D.G. (2014) Quality Changes in High and Low Oil Content Canola during Storage: Part I-Safe Storage Time under Constant Temperatures. Journal of Stored Products Research, 59, 320-327. https://doi.org/10.1016/j.jspr.2014.05.008

[21] Canadian Grain Commission (2018) Official Grain Grading Guide. https://www.grainscanada.gc.ca/oggg-gocg/27/oggg-gocg-27-eng.htm

[22] Systat Software Inc. (2010) Sgmaplot 11.2 User's Guide. Systat Software, Inc., San Jose.

[23] Tipples, K.H. (1995) Quality and Nutritional Changes in Stored Grain. In: Jayas, D.S., White, N.D.G. and Muir, W.E., Eds., Stored Grain Ecosystems, Marcel Dekker Publ. Co., New York, 325-351.

[24] Asad, M., Brahim, M., Ziegler-Devin, I., Boussetta, N. and Brosse, N. (2017) Chemical Characterization of Non-Saccharidic and Saccharidic Components of Rapeseed Hulls and Sunflower Shells. Bioresources, 12, 3143-3153.

https://doi.org/10.15376/biores.12.2.3143-3153

[25] Pronyk, C., Abramson, D., Muir, W.E. and White, N.D.G. (2006) Correlation of Total Ergosterol Levels in Stored Canola with Fungal Deterioration. Journal of Stored Products Research, 42, 162-172. https://doi.org/10.1016/j.jspr.2004.12.004

[26] Cenkowski, S., Sokhansanj, S. and Sosulski, F.W. (1989) The Effect of Drying Temperature on Green Color and Chlorophyll Content of Canola Seed. Canadian Institute of Food Science and Technology Journal, 22, 383-386. https://doi.org/10.1016/S0315-5463(89)70433-8

[27] Cenkowski, S., Jayas, D.S. and Daun, J.K. (1993) Potential of In-Field and Low Temperature Drying for Reducing Chlorophyll Contents in Canola (Brassica napus L). Journal of the Science of Food and Agriculture, 63, 377-383. https://doi.org/10.1002/jsfa.2740630402 